Article

\title{
An Analysis of Behavioral Models Relating to Renewable Energy in Taiwan
}

\author{
Cheng-Chih Chou ${ }^{1,2}$ and Liang-Rui Chen ${ }^{1, *}$ \\ 1 Department of Electrical Engineering, National Changhua University of Education, Changhua 50074, Taiwan; \\ chou@itri.org.tw \\ 2 Green Energy and Environment Research Laboratories, Industrial Technology Research Institute, \\ Hsinchu 31057, Taiwan \\ * Correspondence: Irchen@cc.ncue.edu.tw
}

Citation: Chou, C.-C.; Chen, L.-R An Analysis of Behavioral Models Relating to Renewable Energy in Taiwan. Sustainability 2021, 13, 7296. https://doi.org/10.3390/su13137296

Academic Editors: Michael K.

H. Leung, Wen Tong Chong,

Bernard Saw Lip Huat and Tran Van Man

Received: 14 May 2021

Accepted: 22 June 2021

Published: 29 June 2021

Publisher's Note: MDPI stays neutral with regard to jurisdictional claims in published maps and institutional affiliations.

Copyright: (c) 2021 by the authors. Licensee MDPI, Basel, Switzerland. This article is an open access article distributed under the terms and conditions of the Creative Commons Attribution (CC BY) license (https:// creativecommons.org/licenses/by/ $4.0 /)$.

\begin{abstract}
This study sought to understand the behaviors and attitudes of people in Taiwan as they relate to the government's RE policies by analyzing data from a questionnaire-based telephone survey conducted between 2013 and 2015. Demographic attributes in people's behavioral models were analyzed for two variables: attention and support. Based on the findings, people's behavioral models relating to RE were classified into five categories: key promotional group, promotional seed group, support-strengthening group, attention-strengthening group, and non-key promotional group. The attributes of these five segments were also analyzed and their corresponding promotional strategies were formulated. The overarching goal was to improve precision in marketing RE policies to various target groups in order to maximize impact.
\end{abstract}

Keywords: renewable energy behavioral model; public policy marketing; target group

\section{Introduction}

Taiwan generates almost none of its own energy, with $97.9 \%$ of the total energy consumption depending on imports in 2019; almost all imported fossil fuel was from turbulent areas such as the Middle East [1]. Taiwan is heavily reliant on the import of fossil fuel because of its lack of energy reserves, which is due to an unstable source of import and fluctuating energy prices. Significant greenhouse gas (GHG) is emitted in the use of fossil fuels, and this aggravates the plight of global warming. In addition, since the 2011 Fukushima nuclear disaster, Taiwan's government has been working towards a nuclear energy reduction policy. Influenced by this incident, Taiwan's earlier opposition to nuclear power was further intensified [2]. In 2016, Taiwan government is committed to developing renewable energy and building a nuclear free homeland [3].

With a view to introduce renewable energy (RE) into its electricity supply, Taiwan introduced the Renewable Energy Development Act on 12 June 2009. By actively implementing this act, it is hoped that it will achieve the triple-win goal, i.e., a reduction in GHG emission, an improvement in energy diversity, and a promotion in green-energy industries [4]. The act aims to promote rapid RE development in Taiwan with measures such as establishing feed-in tariffs to provide financial incentives for installing RE-generating equipment along with other complementing stimuli and initiatives. By 2025, Taiwan will generate 20 percent of its electricity through renewable energy, the capacity of renewable power is expected to reach 26.9 gigawatts (GW) within five years [5].

On account of worsening energy security and GHG emissions, Taiwan needs an RE policy to address these problems. The RE policy should ultimately address the needs and opportunities in the social, environmental, and economic dimensions of sustainable development [6]. It is imperative to engage more people in this endeavor, to support RE development and, in turn, to take action and become more willing to install RE-generating equipment. With these objectives in mind, this study analyzed data collected in the past 
using a questionnaire to survey people's RE concept. Further analysis was carried out on the attributes and varieties of the target populations to examine their attention and support and the effectiveness of the promotional efforts.

\section{Literature Review and Research Issues}

The government formulates various policies to support national development, but such policies require the support and approval of its citizens to go beyond mere windowdressing and to avert failure. The government needs to make sure to release information and to make it available to the public for informed discussion and participation. This dialogue, in turn, will promote the collaborative decision-making process by including the public in the inception of new government policies [7].

Moreover, the implementation of policies also requires the participation of both the public and private sectors. Therefore, efforts must be made to fully inform citizens on any policy so that they will support it, contribute to its success, and achieve the original goal set out by the policy.

This study adopted the method of documentary analysis and compiled local and international data to explore concepts and theories on marketing, policy marketing, and behavioral models in order to analyze motivation and behavioral models relating to people's engagement in RE.

\subsection{Literature Review}

\subsubsection{Marketing}

The underlying marketing concept dictates the success or failure of a product; first and foremost is establishing the right theme and idea. To do so, one must get into the shoes of the customer, place their finger on the pulse of the times, and be in tune with the changing needs in this modern era. The most concise definition of marketing is the identification and fulfillment of customer needs. Marketing is one of the key tools in running a business; in business, any contact or transaction with customers may be deemed marketing. Thus, the objective of marketing is to engage customers in consumption behavior, which means to communicate customer needs via marketing maneuvers so that they are willing to purchase the product or service. In addition, marketing is also a social process by which individuals and communities may fulfill their own needs and desires through creating, providing, and freely trading with others valued products and services [8-10].

The application of marketing concepts in the industrial and business spheres has enjoyed a long history, and many conclusions have been drawn by scholars. One such conclusion is that buyer needs must be emphasized and fulfilled in every stage from the creation and transport to the final consumption of a product. Another states that marketing is a business activity that guides the flow of goods and labor from the producer toward the user. The goal of marketing is to truly understand customers and perfectly match the product or service offered with their needs. Once this goal is achieved, the product speaks for itself $[11,12]$.

\subsubsection{Policy Marketing}

The term "social marketing" was first coined by Philip Kotler and Gerald Zaltman in the year 1971. The nature of the social goal is complex, and social marketing is a purposedriven platform aimed at bringing improvement in the targeted society as defined by the driving forces behind it. The principles of commercial marketing hold good for social marketing [13].

Policy/social marketing is also defined to be the adaptation of commercial marketing technologies to programs designed to influence the voluntary behavior of target audiences to improve their personal welfare and that of the society of which they are a part $[14,15]$.

Shih-Hsien Chang [16] has argued that policy marketing is an important way to improve policy promotion. Policy marketing can be simply defined as follows: the dynamic process in which the public sector adopts effective marketing strategies and methods to 
help forge consensus or resonance on a proposed or established public policy within its internal executive personnel and external service recipients. Its objective is to boost the likelihood of success in implementing the policy and enhance a country's competitiveness, thereby achieving the goal of the public good. There may well be good intentions behind the formulation or amendment of a policy, but such intentions would be in vain if the related people were unaware of its purpose and it fails to be fully implemented. In this light, policy marketing is an integral part to effective policy management. Any endeavor undertaken by the government must be marketed. Moreover, some strategies, whether coming from the central or local government, need to have consensus forged through policy marketing. When done in an effective way, policy marketing may not only engender changes in the entire government system and behavioral model but also serve as social education and mobilize public support to foster the thorough execution of a policy $[15,16]$.

Policy marketing is a continuous process and action-the full effect of dialogue and communication may be achieved through constant informing, convincing, and reminding to hopefully shape people's attitude and behavior toward a policy. The greatest challenge in policy marketing is how to achieve "effectiveness." That is to say, to make the policy convincing and, through continuous communication, to inform people of the government's policy to the end of giving their support. As such, effective policy marketing is a way to acquire popular support for a policy $[17,18]$.

Policy marketing applies policy tools to help the government and stakeholders achieve a goal together, whereas policy-marketing behavior is the implementation of policy through marketing approaches. This insight is a key concept and text to the field of policy marketing in Taiwan. Aside from passively applying marketing techniques to convey messages, soften public disapproval, and then change "customer" opinion to achieve the expected behavior, it is even more important, in policy marketing, to actively scout out public sentiments, collect customer expectations, and establish channels to engage citizens in public affairs before a policy is formulated $[15,19,20]$.

Hence, when a policy is being implemented, the government must consider the adequacy of the internal (involved departments and other departments) and external (private sector) environment as well as the target groups of the policy. The marketing strategies must simultaneously cater to internal and external actors to gain support and cooperation from both sides. Furthermore, one success factor in policy marketing is to convey the policy and its related ideas to the public via commercial marketing techniques in order to promote it and then change public behaviors and attitudes. The following four selective tendencies should be included as the key factors [21]:

1. Change in cognition

People's interest in a specific issue must be evoked. People's reaction to a message being promoted may be characterized in three ways. The first is "selected attention," which means that when individuals choose the information they are exposed to, they usually only select messages that garner their interest. The second is "selected distortion," which refers to different interpretations of the same information received due to different values or beliefs. The third is "selected retention," which refers to individuals' deciding whether to retain in memory the information received subject to their level of support. These three selective tendencies often determine the success of policy marketing.

2. Change in action

Marketing seeks to bring about change in people toward a short-term and specific action, e.g., incidental events like galvanizing people to donate blood within a short time. There is a cost to changing people's action, so the content of a marketing campaign must give them incentives so as to trigger changes toward a specific action.

3. Change in behavior

It is one thing to make people accept a different short-term view or change a specific action, such as quitting smoking or drinking or changing dietary habits, and another to change their behavioral model. The latter requires longer-term and continuous efforts. 


\section{Ultimate change in values}

Values are all-encompassing and closely related to individuals' personal formative years and learning environment. To achieve behavior changes in many people, therefore, necessitates the investment of significant administrative resources during the planning and preparatory stages of a policy in order to gain an insight into the background of the public or specific groups with the goal of effectively targeting their needs.

Popular opinion and creativity are the soul of policy marketing. The following two conclusions regarding policy marketing can be drawn after analyzing research and discussion in literature on this topic:

- Policy marketing and identifying citizens' needs have always been key challenges encountered by the public sector when it engages in marketing. Policy implementation requires public support and consensus to boost its chance of success.

- Strategies for marketing a policy require new thinking in the planning stage, and the policy implementation must employ 360-degree marketing aimed at fulfilling people's specific needs.

\subsubsection{Behavioral Model}

If $\mathrm{RE}$ is regarded as a product or brand to be marketed, then the population engaging in RE-related behaviors may be seen as the consumers of RE. Consumer behavior refers to decisions and actions involved when people purchase and use a product or service. In other words, the consumer behavioral model refers to any activity, opinion, or impact related to the process of consumers' purchase of a product or service. Extending this idea into the realm of RE promotion, the series of activity and the decision-making process from the consumer obtaining information to engaging in RE promotional behaviors may be regarded as the RE behavioral model. Consumer behavioral models may be generally classified as follows:

\section{The Engel-Kollat-Blackwell Model (EKB Model)}

The Engel-Kollat-Blackwell model is essentially a conscious problem solving and learning model of consumer behavior. This model has a good description of active information seeking and evaluation processes of consumers. This model shows components of decision making and the relationship and interaction among them. In their model of consumer behavior, the authors viewed consumer behavior as a decision process and identified five activities occurring in this decision process over a period of time [22].

Consumer behavior is a decision-making process that is a continuous or iterative process rather than isolated individual behaviors, and a decision-making model of consumer behavior has been developed from this perspective. The decision-making process in the EKB model is divided into five stages: problem awareness, information search, evaluation of alternatives, purchase, and post-purchase evaluation. The matching and fulfilling of consumers' willingness to purchase and their enjoyment of a service is a dynamic and continuous process. Meanwhile, the purchasing process involves the collection and evaluation of information and the purchase, use, handling, and service of a product. In other words, if the goal is to garner people's support and engage them in the implementation of RE policies, the decision-making model of consumer behaviors should be referenced in the related promotional efforts [23].

\section{Kotler Model}

This model is a framework for a consumer behavioral model comprising the following dimensions: the external environment (e.g., economic, technological, and political aspects), marketing stimuli (e.g., product, price, place, and promotion), buyer characteristics (e.g., cultural and personal), the buying decision process (e.g., problem recognition, information search, evaluation of alternatives, purchase decision, and post-purchase behavior), and buyer decisions (e.g., product choice, brand choice, dealer choice, purchase quantity, and purchase timing). 
The Kotler model is frequently applied in formulating strategies for policy marketing or social marketing by analyzing the purchasing or supporting behavior of the consumer (i.e., citizen) [24].

\section{AIDA Model:}

Upon receiving product information (e.g., advertising), consumers develop an attitude, perception, recognition, and recollection; they then take action until they have completed their consumption behavior (purchase). This is also known as the advertising effect. Attention, interest, desire, and action (AIDA) are further explained as a series of psychological changes and the final purchasing behavior as a result of consumers' perception of advertising. Hence, a successful product promoter must be able to draw the consumer's attention and generate sufficient interest to motivate a purchase, thereby prompting the consumption behavior [25].

Thus, AIDA represents a four-stage sequence in which consumers' attention is attracted, interest is generated, a desire to own is formed, and, finally, real action is taken. Each stage is elaborated below:

- Attention The goal every marketing practitioner strives to achieve is to attract consumers' eyes with marketing media such as advertising, public relations (PR) campaigns, promotions, and activities. Common ways to catch consumers' attention in cyberspace include lucky draws, gifts, freebies, and sensational headlines, all of which are aimed at raising consumers' awareness of online advertising.

- Interest Once consumers have taken notice of the advertising, whether or not they become engaged is highly correlated to its content and the consumers themselves. Key points include whether or not the advertised content is attractive or distinctive enough and whether the individual consumer is interested in such content.

- Desire Advertising may evoke the interest of consumers but not necessarily their desire. Marketing through advertising often leverage charming voices, spokespersons with a good image, and beguiling ambience to kindle consumers' desire.

- Action The ultimate goal of marketing is to spur consumers into action. Adding trigger phrases in advertising is one way to motivate consumers to take immediate action. A common example is: "free gift for the first 40 persons!"

\subsection{Research Issues}

A compilation and analysis of related literature has revealed the following behavioral model before consumers would actualize consumption: a series of decision-making processes, collection of information on the external environment among others, assessment of the most feasible option(s), and, finally, decisions on consumption behavior. The objective of policy marketing, as concluded from an analysis of related literature, is for the public to support a policy and actively participate in related affairs, thereby aligning policy and popular opinion. To achieve this, marketing approaches are employed to expose policy-related information so as to familiarize people who are unclear about or resistant to the policy and, in turn, enhance its success rate.

A comparison between consumer behavioral models and policy marketing while referencing the EKB model theory shows that consumers (the policy audience) must first clearly understand the problem at hand. That is, the policy audience must understand the problem the policy is trying to solve. Once there is a clear understanding, the policy audience would then actively collect information and seek out information related to the problem - a stage tantamount to the "information collection" stage in the EKB model. After problem analysis and information collection, the policy audience would assess the best feasible solution. In theory, if the policy has the audience's support, this best feasible solution will correspond with measures the policy is trying to implement. Finally, the audience would carry out the related measures based on what they have assessed to be the best feasible solution. From the perspective of policy marketing, the aforementioned stage may be seen as the audience taking action to participate in the actual implementation of the policy. 
Based on the above comparative analysis, two key factors must be in place in any audience most likely to take action on a given policy. First, they need to be someone who would actively pay attention to the related issues because that determines whether or not they would actively collect the related information. The other is their support for the policy, which would also reflect their approval of the solution proposed by the government. If the audience actively pays attention to related issues and information and supports the policy, they form a population mostly likely to partake in actions related to the policy, which is, in the context of this study, RE. In other words, they would be willing to support and cooperate with government policies to promote RE.

\section{Methods}

This study was conducted by examining related literature and analyzing RE behavioral models based on a 2013 and 2015 telephone survey of people in Taiwan about their concept and cognition of RE. An analysis was undertaken focusing on two variables measured in the survey: attention on RE and support in RE policy. Based on these variables, an inductive analysis using a matrix was applied to explore the demographic distribution and attributes of Taiwanese populations in their RE participation.

\subsection{Investigation Methods}

Using stratified random sampling, Taiwan (Republic of Taiwan (ROC)) was divided into 19 zones based on municipalities. The required number of samples from each stratum was allocated according to the ratio of the population 18 and above within each zone and the same ratio within the total national population. Population data was taken from statistics for each municipality (Taiwan island proper and the offshore islands of Penghu, Kinmen, and Matsu) from the "ROC Interior Affairs Monthly Gazette of Statistics" compiled by the Ministry of the Interior. As of the end of February 2017, the total number of people 18 or above in Taiwan was 19,352,791 [24].

The sampling population was taken from the telephone directory listing for registered landline users in Taiwan. Since this is not a comprehensive list, random digit dialing (RDD) $[26,27]$ was deployed to ensure an equal chance for everyone in the surveyed zone to be interviewed. Namely, RDD sampling was done using the last two digits in the home phone numbers listed in the directory to ensure those not registered also had the same chance of being interviewed. Should there be two or more persons 18 years or older in the same sampled household, one of them was randomly selected.

\subsection{Quadrant Setup for the RE Promotion Strategy Matrix}

To understand the attributes of RE policy audience, this study formulated an analysis matrix for RE promotion strategies based on data regarding support in RE development and the level of attention on related information of the interviewed subjects. The matrix is explained as follows:

To concretely assess the types of target groups for policy promotion, the matrix was used to clearly delineate the attributes of each. The analytical concept used "attention on RE" and "support in RE policies" as the classifying basis. Four-Quadrant Matrix used in this study and shown as Figure 1. In this four-quadrant matrix, $\mathrm{X}$ axis (horizontal axis) is the degree of attention on RE; $y$ axis (vertical axis) is the degree of support in RE policies.

Firstly, "Support in RE policies" and "attention on RE" had been surveyed using the attitude scale. After eliminating samples where subjects "decline to answer," the scores were converted as follows: for "support in RE policies," strong support = 5 points, moderate support $=4$ points, average support $/$ no opinion $=3$ points, little support $=2$ points, strong disapproval = 1 point. For "attention on RE," "I would actively pay attention to RE-related information via various channels" = 3 points, "I would look at any RE-related information presented to $\mathrm{me}^{\prime \prime}=2$ points, and "I do not pay special attention to RE-related information" = 1 point. 
Then, setting of origin: "positive support" (4 points) under "RE policy Support" (X axis) and "would pay attention" (2 points) under "RE policy attention" (Y axis) were set as the starting point. Coordinates were marked in the corresponding quadrant based on the average support and attention scores of each interviewed group.

Finally, different promotional strategies correspond to different groups in the four quadrants, and the key promotional group and the promotional seed group are distinguished as detailed in the Figure 1.

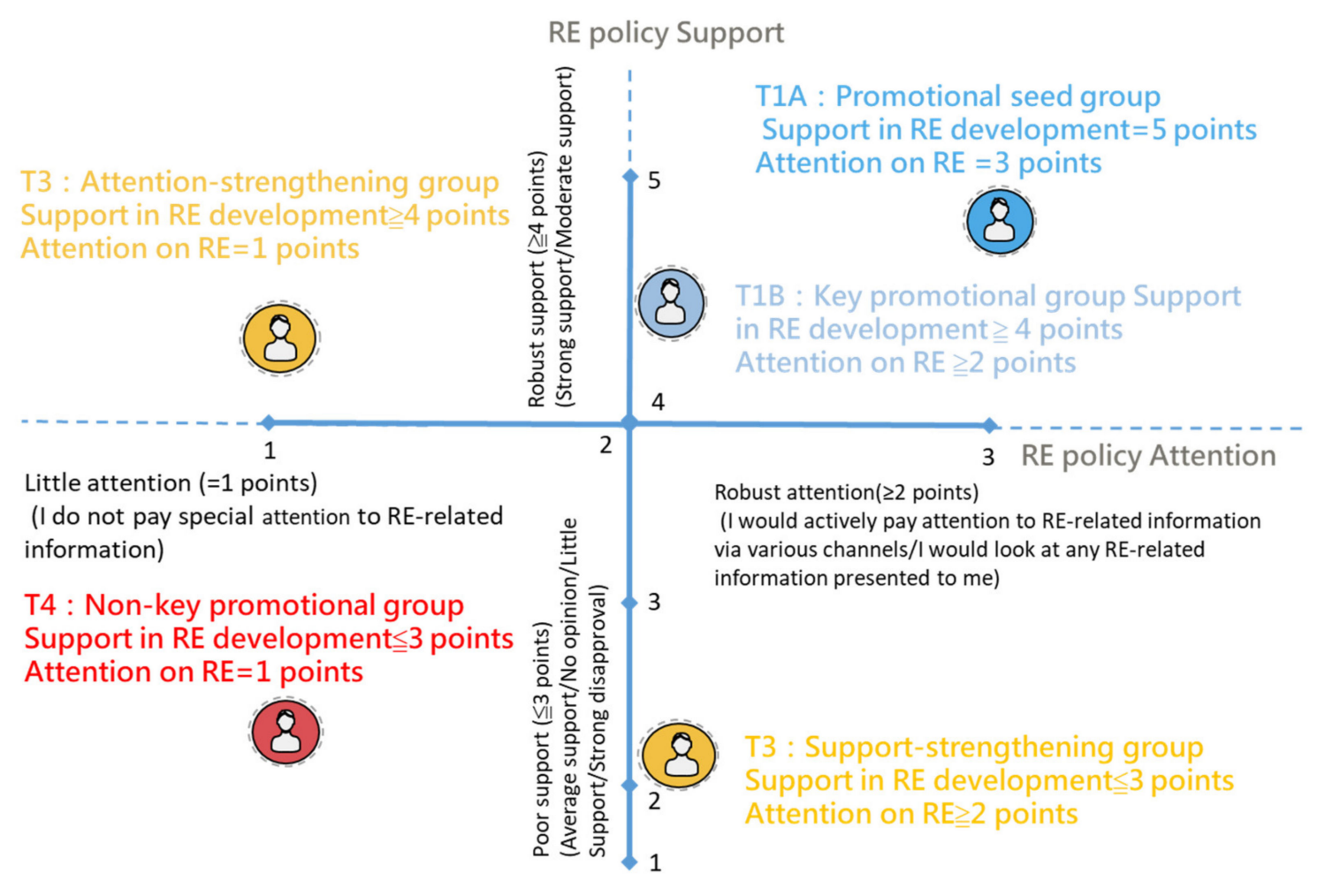

Figure 1. Implications of RE promotion strategy matrix.

\section{Verification of Results of Telephone Interview and Analysis of Target Groups}

4.1. Distribution and Verification of Valid Samples

In a nationwide population-based cross-sectional survey, participants were selected by computerized random sampling from 19 zones. A total 11,058 interviewees were actually contacted. Those who refused to answer and did not fully answer the question set were regarded as invalid samples. The success rate of this interview was $9.79 \%$. There were a total of 1083 valid samples, with $95 \%$ reliability and a $\pm 3.00 \%$ sampling error.

The sampling ratios for various zone, age, and gender were set by proportional allocation. The distribution of valid samples and actual completed samples are detailed in the tables below (Tables 1-3). 
Table 1. Distribution of valid samples by zone.

\begin{tabular}{|c|c|c|c|c|c|c|}
\hline & Zone & $\begin{array}{l}\text { Population }(N) \\
\text { Age } \geq 18\end{array}$ & \multicolumn{2}{|c|}{ Ratio } & \multicolumn{2}{|c|}{ Sample $(n)$} \\
\hline \multirow{7}{*}{ North } & Keelung City & 318,573 & $1.6 \%$ & \multirow{7}{*}{$45.5 \%$} & 17 & \multirow{7}{*}{487} \\
\hline & New Taipei City & $3,337,342$ & $17.2 \%$ & & 175 & \\
\hline & Taipei City & $2,237,743$ & $11.6 \%$ & & 128 & \\
\hline & Taoyuan City & $1,738,016$ & $9.0 \%$ & & 103 & \\
\hline & Hsinchu County & 435,054 & $2.2 \%$ & & 22 & \\
\hline & Hsinchu City & 344,828 & $1.8 \%$ & & 21 & \\
\hline & Yilan County & 384,311 & $2.0 \%$ & & 21 & \\
\hline \multirow{5}{*}{ Central } & Miaoli County & 462,644 & $2.4 \%$ & \multirow{5}{*}{$24.8 \%$} & 30 & \multirow{5}{*}{276} \\
\hline & Taichung City & $2,253,094$ & $11.6 \%$ & & 127 & \\
\hline & Changhua County & $1,063,213$ & $5.5 \%$ & & 56 & \\
\hline & Nantou County & 428,321 & $2.2 \%$ & & 29 & \\
\hline & Yunlin County & 584,268 & $3.0 \%$ & & 34 & \\
\hline \multirow{8}{*}{ South \& East } & Chiayi County & 444,130 & $2.3 \%$ & \multirow{7}{*}{$29.9 \%$} & 21 & \multirow{7}{*}{320} \\
\hline & Chiayi City & 219,945 & $1.1 \%$ & & 17 & \\
\hline & Tainan City & $1,585,755$ & $8.2 \%$ & & 84 & \\
\hline & Kaohsiung City & $2,339,534$ & $12.1 \%$ & & 129 & \\
\hline & Pingtung County & 712,623 & $3.7 \%$ & & 44 & \\
\hline & Taitung County & 185,502 & $1.0 \%$ & & 7 & \\
\hline & Hualien County & 277,895 & $1.4 \%$ & & 18 & \\
\hline & Total & $19,352,791$ & $100 \%$ & & \multicolumn{2}{|c|}{1083} \\
\hline
\end{tabular}

Table 2. Distribution of valid samples by age.

\begin{tabular}{cccc}
\hline Age & Population $(N)$ & Ratio & Sample $(n)$ \\
\hline $18-19$ & 574,874 & $3.0 \%$ & 29 \\
\hline $20-24$ & $1,589,126$ & $8.2 \%$ & 81 \\
\hline $25-29$ & $1,584,263$ & $8.2 \%$ & 90 \\
\hline $30-34$ & $1,750,432$ & $9.0 \%$ & 98 \\
\hline $35-39$ & $2,004,374$ & $10.4 \%$ & 113 \\
\hline $40-44$ & $1,820,542$ & $9.4 \%$ & 107 \\
\hline $45-49$ & $1,802,953$ & $9.3 \%$ & 103 \\
\hline $50-54$ & $1,837,668$ & $9.5 \%$ & 101 \\
\hline $55-59$ & $1,737,583$ & $9.0 \%$ & 247 \\
\hline Above 60 & $4,650,976$ & $24.0 \%$ & $1080 *$ \\
\hline Total & $19,352,791$ & $100.0 \%$ & \\
\hline Three samples refused to answer their age. & & \\
\hline
\end{tabular}

Table 3. Distribution of valid samples by gender.

\begin{tabular}{cccc}
\hline Gender & Population $(\boldsymbol{N})$ & Ratio & Sample $(\boldsymbol{n})$ \\
\hline Male & $9,539,014$ & $49.3 \%$ & 530 \\
\hline Female & $9,813,777$ & $50.7 \%$ & 553 \\
\hline Total & $19,352,791$ & $100.00 \%$ & 1083 \\
\hline
\end{tabular}

To find out if there was a significant difference between the interviewed sample $(n)$ and the population $(N)$, the representativeness of the sample was verified against the sampling structure for variables including zone, gender, and age (see Tables 4-6). The chi-square test shows that there was no significant difference between the two in terms of zone $(p>0.05)$, gender $(p>0.05)$, or age $(p>0.05)$. This analysis indicates that the structure 
of the sample taken in the survey is consistent with that of the population $(N)$ and that the sample $(n)$ statistics sufficiently represent the population. Therefore, there was theoretical support for the rationality behind applying the survey results to deduce the outcome of the population.

Table 4. Verification of representativeness of the sample by zone.

\begin{tabular}{|c|c|c|c|c|c|}
\hline \multicolumn{6}{|c|}{ Sample Verification by Zone } \\
\hline & \multirow[b]{2}{*}{ Zone } & \multicolumn{2}{|c|}{ Population } & \multicolumn{2}{|c|}{ Sampling } \\
\hline & & Population $(N)$ & Ratio & $\begin{array}{c}\text { Sample } \\
(n)\end{array}$ & Ratio \\
\hline \multirow{7}{*}{ North } & Keelung City & 318,573 & $1.6 \%$ & 17 & $1.6 \%$ \\
\hline & New Taipei City & $3,337,342$ & $17.2 \%$ & 175 & $16.2 \%$ \\
\hline & Taipei City & $2,237,743$ & $11.6 \%$ & 128 & $11.8 \%$ \\
\hline & Taoyuan City & $1,738,016$ & $9.0 \%$ & 103 & $9.5 \%$ \\
\hline & Hsinchu County & 435,054 & $2.2 \%$ & 22 & $2.0 \%$ \\
\hline & Hsinchu City & 344,828 & $1.8 \%$ & 21 & $1.9 \%$ \\
\hline & Yilan County & 384,311 & $2.0 \%$ & 21 & $1.9 \%$ \\
\hline \multirow{5}{*}{ Central } & Miaoli County & 462,644 & $2.4 \%$ & 30 & $2.8 \%$ \\
\hline & Taichung City & $2,253,094$ & $11.6 \%$ & 127 & $11.7 \%$ \\
\hline & Changhua County & $1,063,213$ & $5.5 \%$ & 56 & $5.2 \%$ \\
\hline & Nantou County & 428,321 & $2.2 \%$ & 29 & $2.7 \%$ \\
\hline & Yunlin County & 584,268 & $3.0 \%$ & 34 & $3.1 \%$ \\
\hline \multirow{8}{*}{ South \& East } & Chiayi County & 444,130 & $2.3 \%$ & 21 & $1.9 \%$ \\
\hline & Chiayi City & 219,945 & $1.1 \%$ & 17 & $1.6 \%$ \\
\hline & Tainan City & $1,585,755$ & $8.2 \%$ & 84 & $7.8 \%$ \\
\hline & Kaohsiung City & $2,339,534$ & $12.1 \%$ & 129 & $11.9 \%$ \\
\hline & Pingtung County & 712,623 & $3.7 \%$ & 44 & $4.1 \%$ \\
\hline & Taitung County & 185,502 & $1.0 \%$ & 7 & $0.6 \%$ \\
\hline & Hualien County & 277,895 & $1.4 \%$ & 18 & $1.7 \%$ \\
\hline & Total & $19,352,791$ & $100 \%$ & 1083 & $100 \%$ \\
\hline
\end{tabular}

$\chi^{2}=8.12, \mathrm{df}=18, p=0.98>0.05$; the structure of the sample was consistent with that of the population with no significant difference.

Table 5. Verification of representativeness of the sample by age.

\begin{tabular}{ccccc}
\hline \multicolumn{5}{c}{ Sample Verification by Age } \\
\hline Age & Population $(\boldsymbol{N})$ & Ratio & Sample $(n)$ & Ratio \\
\hline $18-19$ & 574,874 & $3.0 \%$ & 29 & $2.7 \%$ \\
$20-24$ & $1,589,126$ & $8.2 \%$ & 81 & $7.5 \%$ \\
$25-29$ & $1,584,263$ & $8.2 \%$ & 90 & $8.3 \%$ \\
$30-34$ & $1,750,432$ & $9.0 \%$ & 98 & $9.1 \%$ \\
$35-39$ & $2,004,374$ & $10.4 \%$ & 113 & $10.5 \%$ \\
$40-44$ & $1,820,542$ & $9.4 \%$ & 107 & $9.9 \%$ \\
$45-49$ & $1,802,953$ & $9.3 \%$ & 103 & $9.5 \%$ \\
$50-54$ & $1,837,668$ & $9.5 \%$ & 111 & $10.3 \%$ \\
$55-59$ & $1,737,583$ & $9.0 \%$ & 101 & $9.4 \%$ \\
60 and above & $4,650,976$ & $24.0 \%$ & 247 & $22.9 \%$ \\
\hline Total & $19,352,791$ & $100 \%$ & 1080 & $100.0 \%$ \\
\hline
\end{tabular}


Table 6. Verification of the sampling representativeness by gender.

\begin{tabular}{ccccc}
\hline \multicolumn{5}{c}{ Sample Verification by Gender } \\
\hline Gender & Population $(\boldsymbol{N})$ & Ratio & Sample $(\boldsymbol{n})$ & Ratio \\
\hline Male & $9,539,014$ & $49.3 \%$ & 530 & $48.9 \%$ \\
Female & $9,813,777$ & $50.7 \%$ & 553 & $51.1 \%$ \\
Total & $19,352,791$ & $100 \%$ & 1083 & $100 \%$ \\
\hline
\end{tabular}

$\bar{\chi} 2=0.059, \mathrm{df}=1, p=0.81>0.05$; the structure of the sample was consistent with that of the population with no significant difference.

$\chi^{2}=2.7, \mathrm{df}=9, p=0.98>0.05$; the structure of the sample was consistent with that of the population with no significant difference.

\subsection{Analysis of the Target Groups for RE Policy Promotion}

An analysis of the survey data (Tables 7 and 8) shows the "promotional seed group" with significantly higher support in policies and attention on related information account for nearly $10 \%(9.9 \%)$. This group should be the primary focus in promoting RE policies. The majority of the subjects (69.5\%) fell under the "key promotional group," with relatively high support and attention. This group is a key foundation that needs to be bolstered in RE policy promotion.

There was a small group (5.4\%) with lower support but higher attention falling under the "support-strengthening group," where efforts need to concentrate on enhancing support. On the contrary, those with higher support but lower attention falling under the "attention-strengthening group" call for more effort on enhancing attention. This group accounted for roughly $10 \%(11.7 \%)$. The "non-key promotional group" low in both support and attention only made up $3.4 \%$.

The target groups were classified based on the meanings for the matrix of RE promotion strategies set herein as follows: key promotional group, promotional seed group, support-strengthening group, attention-strengthening group, and non-key promotional group. The attributes of each group are detailed below: (see Tables 9-13).

Table 7. Target groups for RE policy promotion.

\begin{tabular}{|c|c|c|c|c|}
\hline \multirow[b]{2}{*}{ Target Group } & \multicolumn{2}{|c|}{ Segmentation Indicators } & \multirow[b]{2}{*}{ Sample $(n)$} & \multirow[b]{2}{*}{ Ratio } \\
\hline & Attention on RE & $\begin{array}{l}\text { Support in RE } \\
\text { Policies }\end{array}$ & & \\
\hline Total sample & 2.01 & 4.30 & 1083 & $100 \%$ \\
\hline Promotional seed group & 3.00 & 5.00 & 107 & $9.9 \%$ \\
\hline Key promotional group & 2.07 & 4.45 & 753 & $69.5 \%$ \\
\hline Support-strengthening group & 2.17 & 2.25 & 59 & $5.4 \%$ \\
\hline Attention-strengthening group & 1.00 & 4.35 & 127 & $11.7 \%$ \\
\hline Non-key promotional group & 1.00 & 2.32 & 37 & $3.4 \%$ \\
\hline
\end{tabular}


Table 8. Comparison of target groups of RE policy promotion.

\begin{tabular}{|c|c|c|c|c|c|c|c|}
\hline \multicolumn{2}{|r|}{ Item } & $\begin{array}{l}\text { Ratio of } \\
\text { Sample }\end{array}$ & $\begin{array}{l}\text { Promotional } \\
\text { Seed Group }\end{array}$ & $\begin{array}{c}\text { Key } \\
\text { Promotional } \\
\text { Group }\end{array}$ & $\begin{array}{l}\text { Support- } \\
\text { Strengthening } \\
\text { Group }\end{array}$ & $\begin{array}{l}\text { Attention- } \\
\text { Strengthening } \\
\text { Group }\end{array}$ & $\begin{array}{c}\text { Non-Key } \\
\text { Promotional } \\
\text { Group }\end{array}$ \\
\hline \multicolumn{2}{|r|}{ Ratio } & $100 \%$ & $9.9 \%$ & $69.5 \%$ & $5.4 \%$ & $11.7 \%$ & $3.4 \%$ \\
\hline \multirow{2}{*}{ Gender } & Male & $48.9 \%$ & $59.8 \%$ & $46.5 \%$ & $52.5 \%$ & $49.6 \%$ & $59.5 \%$ \\
\hline & Female & $51.1 \%$ & $40.2 \%$ & $53.5 \%$ & $47.5 \%$ & $50.4 \%$ & $40.5 \%$ \\
\hline \multirow{9}{*}{ Age } & 24 or below & $10.2 \%$ & $0.9 \%$ & $11.6 \%$ & $11.9 \%$ & $9.4 \%$ & $8.1 \%$ \\
\hline & $25-29$ & $8.3 \%$ & $1.9 \%$ & $9.3 \%$ & $8.5 \%$ & $9.4 \%$ & $2.7 \%$ \\
\hline & $30-34$ & $9.1 \%$ & $4.7 \%$ & $9.3 \%$ & $5.1 \%$ & $13.4 \%$ & $8.1 \%$ \\
\hline & $35-39$ & $10.5 \%$ & $12.1 \%$ & $10.8 \%$ & $1.7 \%$ & $11.0 \%$ & $10.8 \%$ \\
\hline & $40-44$ & $9.9 \%$ & $11.2 \%$ & $9.5 \%$ & $11.9 \%$ & $10.2 \%$ & $10.8 \%$ \\
\hline & $45-49$ & $9.5 \%$ & $10.3 \%$ & $9.9 \%$ & $13.6 \%$ & $7.1 \%$ & $2.7 \%$ \\
\hline & $50-54$ & $10.3 \%$ & $11.2 \%$ & $9.6 \%$ & $22.0 \%$ & $9.4 \%$ & $5.4 \%$ \\
\hline & 55-59 & $9.4 \%$ & $17.8 \%$ & $8.3 \%$ & $6.8 \%$ & $7.9 \%$ & $16.2 \%$ \\
\hline & 60 or above & $22.9 \%$ & $29.9 \%$ & $21.7 \%$ & $18.6 \%$ & $22.0 \%$ & $35.1 \%$ \\
\hline \multirow{3}{*}{$\begin{array}{l}\text { zone of } \\
\text { residence }\end{array}$} & North & $45.0 \%$ & $46.7 \%$ & $45.2 \%$ & & $40.9 \%$ & \\
\hline & Central & $25.5 \%$ & $22.4 \%$ & $24.7 \%$ & $32.2 \%$ & $30.7 \%$ & $21.6 \%$ \\
\hline & South/East & $29.5 \%$ & $30.8 \%$ & $30.1 \%$ & $13.6 \%$ & $28.3 \%$ & $43.2 \%$ \\
\hline \multirow{5}{*}{$\begin{array}{l}\text { Level of } \\
\text { education }\end{array}$} & $\begin{array}{l}\text { Lower secondary } \\
\text { or below }\end{array}$ & $15.8 \%$ & $18.7 \%$ & $14.8 \%$ & $17.2 \%$ & $16.7 \%$ & $21.6 \%$ \\
\hline & Higher secondary & $28.2 \%$ & $31.8 \%$ & $27.0 \%$ & $27.6 \%$ & $30.2 \%$ & $35.1 \%$ \\
\hline & Vocational & $12.6 \%$ & $11.2 \%$ & $12.4 \%$ & $19.0 \%$ & $12.7 \%$ & $10.8 \%$ \\
\hline & Undergraduate & $35.0 \%$ & $19.6 \%$ & $38.0 \%$ & $29.3 \%$ & $34.9 \%$ & $29.7 \%$ \\
\hline & Post-graduate & $8.4 \%$ & $18.7 \%$ & $7.8 \%$ & $6.9 \%$ & $5.6 \%$ & $2.7 \%$ \\
\hline \multirow{5}{*}{$\begin{array}{l}\text { Average } \\
\text { household } \\
\text { income } \\
\text { (NTD) }\end{array}$} & 30,000 or less & $18.1 \%$ & $16.9 \%$ & $16.9 \%$ & $15.9 \%$ & $25.8 \%$ & $26.9 \%$ \\
\hline & $30,001-50,000$ & $24.0 \%$ & $19.1 \%$ & $23.9 \%$ & $20.5 \%$ & $29.0 \%$ & $30.8 \%$ \\
\hline & $50,001-80,000$ & $24.1 \%$ & $20.2 \%$ & $25.6 \%$ & $25.0 \%$ & $18.3 \%$ & $19.2 \%$ \\
\hline & $80,001-100,000$ & $12.0 \%$ & $13.5 \%$ & $12.5 \%$ & $11.4 \%$ & $6.5 \%$ & $15.4 \%$ \\
\hline & 100,000 or above & $21.8 \%$ & $30.3 \%$ & $21.0 \%$ & $27.3 \%$ & $20.4 \%$ & $7.7 \%$ \\
\hline \multirow{5}{*}{ Occupation } & $\begin{array}{l}\text { Military/government/ } \\
\text { education or school }\end{array}$ & $12.1 \%$ & $9.3 \%$ & $12.9 \%$ & $10.3 \%$ & $12.2 \%$ & $5.6 \%$ \\
\hline & $\begin{array}{c}\text { Private } \\
\text { corporations }\end{array}$ & $50.7 \%$ & $46.7 \%$ & $50.9 \%$ & $51.7 \%$ & $54.5 \%$ & $44.4 \%$ \\
\hline & Farming/forestry / & & & & & & \\
\hline & $\begin{array}{l}\text { fishing/livestock } \\
\text { or self-employment }\end{array}$ & $6.5 \%$ & $9.3 \%$ & $6.2 \%$ & $5.2 \%$ & $4.1 \%$ & $13.9 \%$ \\
\hline & $\begin{array}{l}\text { Unemployment/ } \\
\text { retire- } \\
\text { ment/homemaking }\end{array}$ & $30.7 \%$ & $34.6 \%$ & $30.0 \%$ & $32.8 \%$ & $29.3 \%$ & $36.1 \%$ \\
\hline
\end{tabular}

Table 9. Features of promotional seed group.

\begin{tabular}{|c|c|}
\hline Attributes & Description \\
\hline Gender & The ratio of male subjects was higher than the rate of Sample. \\
\hline Age & The ratio of subjects aged 35 or above was higher than the rate of Sample. \\
\hline zone of residence & $\begin{array}{l}\text { The ratio of subjects living in North or South/East Taiwan was higher than the rate of } \\
\text { participants. }\end{array}$ \\
\hline Level of education & $\begin{array}{l}\text { The ratio of subjects with upper secondary education or below or at least } \\
\text { post-graduate education was higher than the rate of Sample. }\end{array}$ \\
\hline Average household income & $\begin{array}{l}\text { The ratio of subjects with an average household income of NTD } 80,000 \text { or above was } \\
\text { higher than the rate of Sample. }\end{array}$ \\
\hline Occupation & $\begin{array}{l}\text { The ratio of subjects in farming/forestry/fishing/livestock or self-employment or } \\
\text { unemployment/retirement/homemaking was higher than the rate of Sample. }\end{array}$ \\
\hline Awareness of RE equipment & $\begin{array}{l}\text { The ratio of subjects with an awareness of RE equipment was higher than the rate } \\
\text { of Sample. }\end{array}$ \\
\hline Willingness to install RE equipment & $\begin{array}{l}\text { The ratio of subjects willing to install RE equipment was higher than the rate } \\
\text { of Sample. }\end{array}$ \\
\hline Awareness of green electricity & $\begin{array}{l}\text { The ratio of subjects with an awareness of green electricity was higher than the rate } \\
\text { of Sample. }\end{array}$ \\
\hline Willingness to buy green electricity & The ratio of subjects willing to buy green electricity was higher than the rate of Sample. \\
\hline
\end{tabular}


Table 10. Features of key promotional group.

\begin{tabular}{|c|c|}
\hline Attributes & Description \\
\hline Gender & The ratio of female subjects was higher than the rate of Sample. \\
\hline Age & The ratio of subjects aged 39 or below, or $45-49$ was higher than the rate of Sample. \\
\hline zone of residence & $\begin{array}{l}\text { The ratio of subjects living in North or South/East Taiwan was higher than the rate of } \\
\text { Sample. }\end{array}$ \\
\hline Level of education & $\begin{array}{l}\text { The ratio of subjects with undergraduate education) was higher than the rate of } \\
\text { Sample. }\end{array}$ \\
\hline Average household income & $\begin{array}{l}\text { The ratio of subjects with an average household income of NTD50,000-100,000 was } \\
\text { higher than the rate of Sample. }\end{array}$ \\
\hline Occupation & $\begin{array}{l}\text { The ratio of subjects in military/government/education/school or private } \\
\text { corporations was higher than the rate of Sample. }\end{array}$ \\
\hline Awareness of RE equipment & $\begin{array}{l}\text { The ratio of subjects with an awareness of RE equipment was higher than the rate of } \\
\text { Sample. }\end{array}$ \\
\hline Willingness to install RE equipment & $\begin{array}{l}\text { The ratio of subjects willing to install RE equipment was higher than the rate of } \\
\text { Sample. }\end{array}$ \\
\hline Awareness of green electricity & The ratio of subjects with an awareness of RE was higher than the rate of Sample. \\
\hline Willingness to buy green electricity & The ratio of subjects willing to buy green electricity was higher than the rate of Sample. \\
\hline
\end{tabular}

Table 11. Features of support-strengthening group.

\begin{tabular}{|c|c|}
\hline Attributes & Description \\
\hline Gender & The ratio of male subjects was higher than the rate of Sample. \\
\hline Age & The ratio of subjects aged 29 or below or $40-54$ was higher than the rate of Sample. \\
\hline zone of residence & $\begin{array}{l}\text { The ratio of subjects living in North or Central Taiwan was higher than the rate of } \\
\text { Sample. }\end{array}$ \\
\hline Level of education & $\begin{array}{l}\text { The ratio of subjects with lower secondary education or below or vocational education } \\
\text { was higher than the rate of Sample. }\end{array}$ \\
\hline Average household income & $\begin{array}{l}\text { The ratio of subjects with an average household income of NTD50,000-80,000 or } \\
\text { NTD100,000 or above was higher than the rate of Sample. }\end{array}$ \\
\hline Occupation & $\begin{array}{l}\text { The ratio of subjects in private corporations or unemployment/ } \\
\text { retirement/homemaking was higher than the rate of Sample. }\end{array}$ \\
\hline Awareness of RE equipment & $\begin{array}{l}\text { The ratio of subjects who have never heard of RE equipment was higher than the rate } \\
\text { of Sample. }\end{array}$ \\
\hline Willingness to install RE equipment & $\begin{array}{l}\text { The ratio of subjects unwilling to install RE equipment was higher than the rate of } \\
\text { Sample. }\end{array}$ \\
\hline Awareness of green electricity & $\begin{array}{l}\text { The ratio of subjects who have never heard of green electricity was higher than the } \\
\text { rate of s Sample s. }\end{array}$ \\
\hline Willingness to buy green electricity & $\begin{array}{l}\text { The ratio of subjects unwilling to buy green electricity was higher than the rate of } \\
\text { Sample. }\end{array}$ \\
\hline
\end{tabular}


Table 12. Features of attention-strengthening group.

\begin{tabular}{|c|c|}
\hline Attributes & Description \\
\hline Gender & The ratio of male subjects was higher than the rate of Sample. \\
\hline Age & The ratio of subjects aged 44 or below was higher than the rate of Sample. \\
\hline zone of residence & $\begin{array}{l}\text { The ratio of subjects living in North or Central Taiwan was higher than the rate of } \\
\text { Sample. }\end{array}$ \\
\hline Level of education & The ratio of subjects with vocational education was higher than the rate of Sample. \\
\hline Average household income & $\begin{array}{l}\text { The ratio of subjects with an average household income of NTD50,000 or less was } \\
\text { higher than the rate of Sample. }\end{array}$ \\
\hline Occupation & $\begin{array}{l}\text { The ratio of subjects in military/government/education/school or private } \\
\text { corporations was higher than the rate of Sample. }\end{array}$ \\
\hline Awareness of RE equipment & $\begin{array}{l}\text { The ratio of subjects who have never heard of RE equipment was higher than the rate } \\
\text { of Sample. }\end{array}$ \\
\hline Willingness to install RE equipment & $\begin{array}{l}\text { The ratio of subjects unwilling to install RE equipment or providing no comment was } \\
\text { higher than the rate of Sample. }\end{array}$ \\
\hline Awareness of green electricity & $\begin{array}{l}\text { The ratio of subjects who had never heard of green electricity was higher than the rate } \\
\text { of Sample. }\end{array}$ \\
\hline Willingness to buy green electricity & $\begin{array}{l}\text { The ratio of subjects unwilling to buy green electricity or providing no comment was } \\
\text { higher than the rate of Sample. }\end{array}$ \\
\hline
\end{tabular}

Table 13. Features of non-key promotional.

\begin{tabular}{ll}
\hline Attributes & \multicolumn{1}{c}{ Description } \\
\hline Gender & The ratio of male subjects was higher than the rate of Sample. \\
\hline Age & The ratio of subjects aged 35-44 was higher than the rate of Sample. \\
\hline zone of residence & The ratio of subjects living in South Taiwan was higher than the rate of Sample. \\
\hline Average household income & $\begin{array}{l}\text { The ratio of subjects with higher secondary education or below was higher than the } \\
\text { rate of Sample. }\end{array}$ \\
\hline Occupation & $\begin{array}{l}\text { The ratio of subjects with an average household income of NTD50,000 or } \\
\text { NTD80,000-100,000 was higher than the rate of Sample. }\end{array}$ \\
\hline Awareness of RE equipment & $\begin{array}{l}\text { The ratio of subjects in farming/forestry/fishing/livestock/self-employment or } \\
\text { unemployment/retirement/homemaking was higher than the rate of Sample. }\end{array}$ \\
\hline Willingness to install RE equipment & $\begin{array}{l}\text { The ratio of subjects who had never heard of RE equipment was higher than the rate } \\
\text { of Sample. }\end{array}$ \\
\hline Awareness of green electricity & $\begin{array}{l}\text { The ratio of subjects unwilling to install RE equipment or providing no comment was } \\
\text { higher than the rate of Sample. }\end{array}$ \\
\hline Willingness to buy green electricity & $\begin{array}{l}\text { The ratio of subjects who had never heard of green electricity was higher than the rate } \\
\text { of Sample. }\end{array}$ \\
\hline $\begin{array}{l}\text { The ratio of subjects unwilling to buy green electricity or providing no comment was } \\
\text { higher than the rate of Sample. }\end{array}$
\end{tabular}

\subsection{Discussions of the Target Groups of RE Policy Promotion}

A cross analysis of the categories and attributes of the target groups of RE policy promotion revealed significant differences in distribution based on the following attributes: age, level of education, awareness of RE equipment, willingness to install RE equipment, awareness of green electricity, and willingness to buy green electricity.

Awareness in both RE equipment and green electricity appeared higher in male subjects than female ones; awareness in both was significantly lower in those 60 or older than in other age groups. Subjects living in North Taiwan had a higher awareness of RE equipment, whereas those in South/East Taiwan had significantly less. Regarding the 
level of education, those with an undergraduate diploma accounted for the majority of the subjects. As for average household income, those with a monthly income of NTD30,000 or less were at least aware of RE equipment; those at NTD 50,000-80,000 were most willing to buy green electricity; those at NTD 100,000 were most aware of RE equipment but least willing to buy green electricity. Subjects employed by private corporations comprised half of the subjects, with the highest awareness in green electricity, the highest willingness to install RE equipment, and yet the lowest willingness to buy green electricity. Those in the unemployment/retirement/homemaking group had the least awareness of both green electricity and RE equipment.

Findings of the cross analysis indicate that there is a higher proportion of those 60 or above in the non-key promotional group; it is quite clear that they pay less attention to RE-related information compared with other age groups. The key promotional group had a higher ratio of people with an undergraduate degree, making them a key foundation in promoting RE policies because of the potentially highest effectiveness. When it comes to a high awareness and willingness to install/buy RE equipment or green electricity, the promotional seed group contained a higher ratio of these people who actively pay attention to RE information and demonstrated higher support than other groups. Their influence may be leveraged to amplify the effectiveness of RE marketing. Descriptions of the key attributes of each target group and a comparison are outlined in Table 14 below.

Table 14. Descriptions of the target groups of RE policy promotion.

\begin{tabular}{|c|c|}
\hline Item & Trait \\
\hline Age & $\begin{array}{l}24 \text { or below: higher ratio in the support-strengthening group }(11.9 \%) \text {. } \\
\text { 25-29: higher ratio in the attention-strengthening group }(9.4 \%) \text {. } \\
\text { 30-34: higher ratio in the attention-strengthening group }(13.4 \%) \text {. } \\
\text { 35-39: higher ratio in the promotional seed group }(12.1 \%) . \\
\text { 40-44: higher ratio in the support-strengthening group }(11.9 \%) \text {. } \\
\text { 45-49: higher ratio in the support-strengthening group }(13.6 \%) \text {. } \\
\text { 50-54: higher ratio in the support-strengthening group }(22.0 \%) \text {. } \\
\text { 55-59: higher ratio in the promotional seed group }(17.8 \%) \text { and non-key promotional group }(16.2 \%) \text {. } \\
60 \text { or above: higher ratio in the promotional seed group }(29.9 \%) \text { and non-key promotional group } \\
(35.1 \%) \text {. }\end{array}$ \\
\hline Level of education & $\begin{array}{l}\text { Lower secondary or below: higher ratio in the non-key promotional group }(21.6 \%) \text {. } \\
\text { Higher secondary: higher ratio in the non-key promotional group }(35.1 \%) \text {. } \\
\text { Vocational: higher ratio in the support-strengthening group }(19.0 \%) \text {. } \\
\text { Undergraduate: higher ratio in the key promotional group }(38.0 \%) \text {. } \\
\text { Post-graduate: higher ratio in the promotional seed group }(18.7 \%) \text {. }\end{array}$ \\
\hline $\begin{array}{l}\text { Awareness of RE } \\
\text { equipment }\end{array}$ & $\begin{array}{l}\text { Had heard of RE equipment: higher ratio in the promotional seed group (86.0\%). } \\
\text { Had never heard of RE equipment: higher ratio in the non-key promotional group (45.9\%). }\end{array}$ \\
\hline $\begin{array}{l}\text { Willingness to install RE } \\
\text { equipment }\end{array}$ & $\begin{array}{l}\text { Willing to install RE equipment: higher ratio in the promotional seed group ( } 82.2 \%) \text {. } \\
\text { Unwilling to install RE equipment: higher ratio in the support-strengthening group }(49.2 \%) \text { non-key } \\
\text { promotional group }(62.2 \%) \text {. }\end{array}$ \\
\hline $\begin{array}{l}\text { Awareness of green } \\
\text { electricity }\end{array}$ & $\begin{array}{l}\text { Had heard of green electricity: higher ratio in the promotional seed group }(70.1 \%) \text {. } \\
\text { Had never heard of green electricity: higher ratio in the attention-strengthening group }(64.6 \%) \\
\text { non-key promotional group }(62.2 \%) \text {. }\end{array}$ \\
\hline $\begin{array}{l}\text { Willingness to buy green } \\
\text { electricity }\end{array}$ & $\begin{array}{l}\text { Willing to buy green electricity: higher ratio in the promotional seed group }(73.8 \%) \text {. } \\
\text { Unwilling to buy to buy green electricity: higher ratio in the support-strengthening group }(55.9 \%) \\
\text { and non-key promotional group }(64.9 \%) \text {. }\end{array}$ \\
\hline
\end{tabular}

\section{Investigation on Changes among the Groups 2017-2020}

This study used the same questionnaire and survey methods, continued the survey from 2017 to 2020, and tracked changes among the groups between 2017 and 2020, and it compared ratio changes in the groups across the years. The promotional seed group appeared to dwindle, whereas the key promotional group and the non-key pro- 
motional group went first on a decline but then rebounded to their original levels. The support-strengthening group and the attention-strengthening group dropped slightly before reversing into a rising trend. These 2017-2020 changes are reflected in Figure 2.

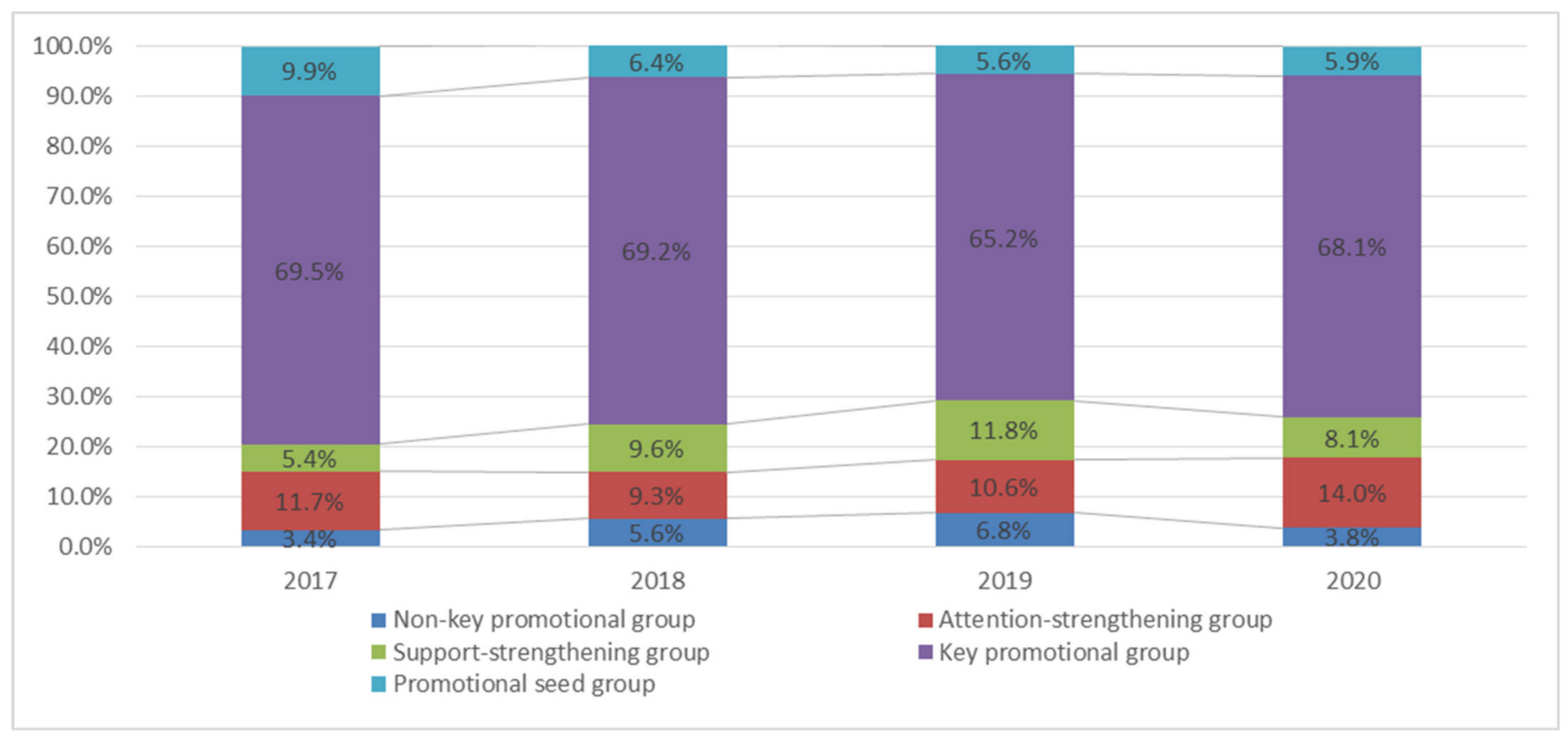

Figure 2. Investigation on changes among the groups 2017-2020.

A probe into people in the promotional seed group shows they tend to take the initiative to learn about RE policies and information compared to the other groups. However, negative news on RE in recent years in Taiwan may have contributed to attrition in this group; some examples include arbitrary disposal of photovoltaic equipment and slow implementation of offshore wind power installations. Although the key promotional group, subjected to the same impact from external information as the promotional seed group, also suffered a decline in ratio in 2018 and 2019, it rebounded in 2020 thanks to the government's implementation of RE policies relevant to the public that boosted RE exposure, such as subsidies on RE equipment installation for indigenous communities or civic societies and rules pertaining to heavy electricity users. Whereas the ratio of the support-strengthening group climbed because of negative news in 2018 and 2019, the government's implementation of several positive policies in 2020 also helped to slightly lower the ratio. Between 2017 and 2019 , fluctuation in the ratio of the attention-strengthening group remained around $\pm 1 \%$ but saw a significant increase in 2020. A possible reason may be that people in this group inherently do not seek out information related to RE policies and require soft activities or promotions to boost their attention, but the COVID-19 pandemic in 2020 caused many large events to be cancelled in Taiwan, in the process reducing exposure to soft RE information that could have been promoted, thus giving rise to a clear increase in this group.

\section{Discussion}

The objective of this study was to deconstruct the distribution of attributes of Taiwanese people according to their attention and support of RE in order to understand their consumption awareness and behavior for the purpose of informing future policy-making or promotion. The data was sourced from a telephone survey conducted between 2013 and 2015 under the "Initiative on the Infrastructure Building and Integrated Development for Applications in Low-carbon Energy." With regards to awareness, approximately $80 \%$ of people in Taiwan have heard of RE and carry a basic understanding of RE varieties and applications. Since RE issues are evidently no longer an esoteric or highly-specialized topic 
for the Taiwanese public, this study predicates its probe into RE behavioral models on this basic and existing level of awareness.

Informative RE policies are those that attempt to influence behavior by means of persuasion, communication, and transfer of knowledge [28,29]. During a review of related literature and findings, few studies examining RE behavioral models and population attributes were found. This study analyzed these aspects using data from a 2013-2015 telephone survey of people's RE concept and awareness, with an aim to gain an insight into the target audiences so as to promote RE through scientific tools. A matrix for RE promotional strategies was also used to decipher the distribution and attributes of each group.

The consolidated findings inform recommendations for future marketing approaches for RE policies; they provide a sound basis for the government to formulate related strategies as they focus on specific groups with effectiveness and precision toward achieving its goals. The following recommendations are offered for the five target groups:

- Promotional seed group

This group demonstrated the highest attention support underpinned by sound RE insight, making them the ideal audience for RE implementation (e.g., installing RE equipment and investing in RE industries). The majority of this group were men 35 years or older with an average household income of NTD80,000 or above. In this age group, $45 \%$ strong of the population attach great importance to information on financial management and fitness maintenance, so marketing strategies for them could accentuate the economic benefits of RE installation or pair the campaigns with fitness-related topics.

Incentives should be devised to motivate them to participate in RE promotional activities, and the word-of-mouth effect may then be amplified through their influence. A two-pronged approach centering on social media marketing and in-person activities may be deployed in RE advertising and marketing. For the former, the cost analysis of RE installation (e.g., photovoltaics) may be provided in Facebook social groups, and data on RE generation published on the government's public platforms may be used to communicate revenue estimates from RE generation to further raise the willingness of this group to invest. In addition, information on how RE development helps improve the environment (e.g., reduction of PM2.5, or fine particulate, and air quality improvement) should also be disseminated to bolster their policy support. When it comes to in-person activities, one-day themed events may be staged leveraging this group's proclivity for fitness and health. For example, walks or runs may be held at destinations featuring RE (e.g., Gaomei Wetlands or Fudekeng Environmental Restoration Park, a former landfill site). This way, they are made aware of Taiwan's RE achievements while they engage in sports-themed activities, reinforcing their support in the process.

- Key promotional group

This group accounted for the highest percentage in the interviewed subjects. Their support and continued attention on RE information may be seen as the outcome of sustained propagation of RE awareness across Taiwan, making them the bedrock for future policy execution. The majority includes people 39 or below and those between $45-29$ with an undergraduate education and an average household income of NTD50,000-100,000. This group takes up $65.2-69.5 \%$ of the total sample and mirrors its distribution attributes. On account of their attention and support, both around $60 \%$, a more in-depth study may be undertaken to learn about the causes and barriers behind their willingness to install RE equipment and thereby to concoct more precise marketing strategies. Policy promotion measures better adapted to this group should also be explored to strengthen and enhance their support and attention. The outcome of promotional effort would be enhanced and may serve as a reference for future policy-making if they can be encouraged into actively seeking out RE information and thus render higher support for RE development.

It is advisable to devise communication channels to spread RE information and continue to study causes and barriers for RE installation. The three current main sources of RE information - television, Internet, and print media—should be expanded to also include 
courses, briefings, and themed seminars. The goal of the diversification is to alleviate people's doubts and make them better informed.

- Attention-strengthening group

People in this group expressed general support for Taiwan's RE policies but, for the most part, have not heard of RE and do not actively pay attention to related issues. The majority are 44 or younger. It is thus advisable to first boost their attention in these issues. To do so, promotional strategies closer to their life should be conceived to give those originally disinterested more opportunities to become enlightened, increasing their attentiveness and thereby raising their awareness and support in policies.

Comics, posters, and graphics on RE topics may be prepared and then promoted via the Internet or in-person activities. For instance, charts explaining RE information or comics may be regularly published on online social platforms. Online marketing campaigns may also be accompanied with lucky draws, matching the target age groups and geographic distribution of the social platforms with the demographic attributes of this group. The overarching aim is to elevate exposure and therefore attention.

- Support-strengthening group

Although people in this group show significant attention in RE topics, they tend to be unwilling to install RE equipment or buy green electricity. Despite accounting for only around $10 \%$, it may be worthwhile to probe the reasons for their dismal support and analyze the causes. Some possible reasons include a lack of understanding of the policies or insufficiency in the policies and related measures in the ability to engage them in RE development.

With the latter reason, further evaluation may be due to determine if adjustments should be made to raise the support of this group. With the former, more emphasis may be placed on marketing policies to those 40-54 years old living in North and Central Taiwan. Policy information may be propagated on television and bus advertising and the Internet to draw their attention and advance their support. A better grasp of their key support factors will contribute to better policy implementation.

- Non-key promotional group

This group was low in support and attention, as well as in percentage. Promotion targeting this group may be delayed if return on resource allocation is a factor. However, one should continue to observe potential causes and any changes in trend. Moreover, overlaps in attributes with the previous four groups should be identified so that policymarketing activities for those four groups can also be supplemented with considerations for this group.

\section{Conclusions}

This study sought to understand the behavior and attitude of people in Taiwan as they relate to the government's RE policies by analyzing data from a questionnaire-based telephone survey conducted between 2013 and 2015.

Demographic attributes in people's behavioral models were analyzed for two variables: attention and support. Through the analysis of attention and support, this study summarized the characteristics of five different ethnic groups, and such characteristics can help the government to develop methods of decision-making and marketing strategies. Improved precision in marketing RE policies to various target groups will maximize impact.

This research suggests that, in a follow-up, we can formulate corresponding marketing strategies based on the promotion suggestions for the five groups and try to conduct a questionnaire survey of 3 to 5 years according to the characteristics of different groups to understand the feedback and effects of the groups on their marketing strategies. 
Author Contributions: C.-C.C.; methodology, C.-C.C.; software, C.-C.C.; validation, C.-C.C. and L.-R.C.; formal analysis, C.-C.C.; investigation, C.-C.C.; resources, C.-C.C.; data curation, C.-C.C.; writing-original draft preparation, C.-C.C.; writing-review and editing, C.-C.C. and Chen, L.-R.C.; visualization, C.-C.C.; supervision, L.-R.C. All authors have read and agreed to the published version of the manuscript.

Funding: This research received no external funding.

Institutional Review Board Statement: Not applicable.

Informed Consent Statement: Not applicable.

Data Availability Statement: Not applicable.

Acknowledgments: The authors would like to thank the Bureau of Energy (BOE) of the Ministry of Economic Affairs in Taiwan for providing support for this study.

Authors are very grateful the Editors and anonymous reviewers for the comments and their interest in our manuscript.

Conflicts of Interest: The authors declare no conflict of interest.

\section{References}

1. Ministry of Economic Affairs (MOEA). 2019 Energy Statistical Data Book; Ministry of Economic Affairs (MOEA): Taipei, Taiwan, 2021.

2. Chang, C.T.; Lee, H.C. Taiwan's renewable energy strategy and energy-intensive industrial policy. Renew. Sustain. Energy Rev. 2016, 64, 456-465. [CrossRef]

3. Executive Yuan, Energy Policy Project Report. Available online: https:/ /www.ey.gov.tw / File/890AE999AEBED01F (accessed on 15 February 2021).

4. Hwang, J.J. Promotional policy for renewable energy development in Taiwan. Renew. Sustain. Energy Rev. 2010, $14,1079-1087$. [CrossRef]

5. Taiwan News. Taiwan to Boost Renewable Energy to $20 \%$ by 2025 , Introduce Trillion-Dollar Investment. Available online: https:/ / www.taiwannews.com.tw/en/news/3880997 (accessed on 30 February 2021).

6. Huang, Y.H.; Wu, J.H. Energy Policy in Taiwan: Historical Developments, Current Status and Potential Improvements. Energies 2009, 2, 623-645. [CrossRef]

7. Chun, S.A.; Shulman, S.; Sandoval, R.; Hovy, E. Government 2.0: Making connections between citizens, data and government. Inf. Polity 2010, 15, 1-9. [CrossRef]

8. Hunt, S.D. The Nature and Scope of Marketing. J. Mark. 1976, 40, 17-28. [CrossRef]

9. Kotler, P. A Generic Concept of Marketing. Mark. Manag. 1988, 7, 48-54.

10. Hastings, G.B.; Elliott, B. Marketing of Traffic Safety; OECD: Paris, France, 2013; pp. 35-53.

11. Chiou, C.; Chang, S. Policy Analysis, 1st ed.; National Open University Publication Center: New Taipei City, Taiwan, 2008; pp. 35-98. ISBN 9789576614132.

12. Chiang, T. Study of Strategies for Urban Marketing with the Case of Kaohsiung City. Master's Thesis, National San Yat-sen University, Kaohsiung City, Taiwan, 2002.

13. Nanda, A.K. Social Marketing: A Literature Review. Int. J. Sci. Res. 2015, 4, 697-702.

14. Buurma, H. Public policy marketing: Marketing exchange in the public sector. Eur. J. Mark. 2001, 35, 1287-1300. [CrossRef]

15. Andreasen, A.R. Social marketing: Its definition and domain. J. Public Policy Market. 1994, 13, 108-114. [CrossRef]

16. Chang, S. Public Policy Analysis, 2nd ed.; WU-NAN Culture Enterprise: Taipei City, Taiwan, 2009; pp. 309-341. ISBN 9789571155081.

17. Wilkie, W.L.; Gardner, D.M. The Role of Marketing Research in Public Policy Decision Making. J. Mark. 1974, $38,38-47$.

18. Huang, J.H. Public Administration, 1st ed.; Sunny Ding Publishing House: Taipei City, Taiwan, 2009; ISBN 9789579563598.

19. Prakash, A. Green Marketing, Publicpolicy and Managerial Strategies. Bus. Strategy Environ. 2002, 11, 285-297. [CrossRef]

20. Lu, B. Research on Public Policy Marketing. Chin. J. Adm. 2007, 78, 31-53.

21. Lo, J. Available online: https:/ / www.moj.gov.tw/cp-305-63547-31c2a-001.html (accessed on 4 March 2021).

22. Jisana, T.K. Consumer behaviour models: An overview. Sai Om J. Commer. Manag. 2014, 1, $34-43$.

23. Chien, M. Consumer Behavior, 3rd ed.; New Wun Ching Developmental Publishing: New Taipei City, Taiwan, 2014; pp. 16-20. ISBN 9789862368787.

24. Gilaninia, S.; Taleghani, M.; Azizi, N. Marketing Mix and Consumer Behavior. Kuwait Chapter 2013, 2, 53-58. [CrossRef]

25. Ghirvu, A.I. The AIDA Model for Advergames. USVAEPA 2013, 13, 090-098.

26. Ministry of the Interior. Statistical Yearbook of Interior (2015); Ministry of the Interior: Taipei, Taiwan, 2016.

27. Glasser, G.J.; Metzger, G.D. Random-Digit Dialing as a Method of Telephone Sampling. J. Mark. Res. 1972, 9, 59-64. [CrossRef] 
28. Cattaneo, C. Internal and external barriers to energy efficiency: Which role for policy interventions? Energy Effic. 2019, 12, 1293-1311. [CrossRef]

29. Kristina, E.; Söderholm, P. The devil is in the details: Household electricity saving behavior and the role of information. Energy Policy 2010, 38, 1578-1587. 